\title{
Application of Modeling Drugs in Animal Models of Chemical Phlebitis: Review
}

\author{
Cuiling Tong, Hong Zhou*, Jing Geng \\ School of Medicine, Yangtze University, Jingzhou, China

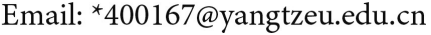

How to cite this paper: Tong, C.L., Zhou, H. and Geng, J. (2019) Application of Modeling Drugs in Animal Models of Chemical Phlebitis: Review. Yangtze Medicine, 3, 19-31.

https://doi.org/10.4236/ym.2019.31003

Received: September 4, 2018

Accepted: December 18, 2018

Published: December 21, 2018

Copyright (c) 2019 by authors and Scientific Research Publishing Inc. This work is licensed under the Creative Commons Attribution International License (CC BY 4.0).

http://creativecommons.org/licenses/by/4.0/

\section{(c) (i) Open Access}

\begin{abstract}
Objective: This review aims to determine the impact of different drugs and methods on the successful establishment of an animal model for chemical phlebitis (CP). Design: Search the Cochrane Library, ProQuest Academic Journal Library, PubMed, Web of Science, Ovid, Embase, CINAHL complete (EESCO) and other related databases to determine the literature. Screen out articles consistent with this review and summarize them. Results: Since the establishment of the database, a total of 1463 articles have been retrieved. After reading the title, abstract and full text, and excluding non-related and duplicate articles, 22 reports were finally included. Among them, there are 8 articles using different medication methods to compare the effects of establishing a CP model. The included articles explored the effects of different animal models, drug types, and their dose, concentration, speed, and time on the CP model. Conclusion: The factors of dose, concentration and time were positively correlated with the incidence of $\mathrm{CP}$. The effect of speed factors on $\mathrm{CP}$ and the results of different animal models are inconsistent. It requires further research in the future.
\end{abstract}

\section{Keywords}

Chemical Phlebitis, Animal Model, Drug

\section{Introduction}

Chemical phlebitis (CP) is a sterile inflammatory reaction caused by the infusion of low $\mathrm{pH}$, high osmotic pressure, high concentration of drugs, and produces chemical stimulation of the intima, vascular endothelial damage and phlebitis as well [1] [2] [3]. Clinical manifestations are local venous redness, fever, pain, swelling, and/or palpable induration [2]. The incidence of CP exceeds is $57.6 \%$ [2] [4]. The high incidence of CP inevitably leads to the removal of the catheter 
and shortens the indwelling time [2] [4].

Researches on the CP have become a hot topic at home and abroad, and have been getting more results. In particular, more achievements have been made in animal experimental research. Application of clinically used stimulant drugs to the veins of animals can establish a CP animal model, and prevent and treat drugs before or after modeling [1] [5] [6]. The method of infusion is reproduced below (Figure 1). The data and results of these experimental studies have greatly contributed to the clinical prevention and treatment of CP.

Currently, the veins of rabbit ear and mouse tail are usually used for puncture modeling. However, the veins of these animal models are susceptible to factors, such as the dose, concentration, speed, and timing of the drug, causing local adverse reaction. As a result, this paper reviews recent advances in modeling drugs for animal models of CP.

\section{Method}

In order to accurately apply the modeled drugs, the animal model of $\mathrm{CP}$ was effectively established. The current status of application of CP animal model drugs was searched. The databases searched were Cochrane Library, ProQuest Academic Journal Library, PubMed, Web of Science, Ovid, Embase, CINAHL complete (EESCO), being the limits articles published since the establishment of the databas, and studies in English, Chinese. "chemical" OR "chemotherapy" OR "chemotherapeutic" OR "infusion" AND "phlebitis" phlebitis, "intravenous" OR "vein” OR "blood vessel” AND "damage" AND "animal” OR "rabbit" OR "mouse" OR "dog", "model" OR "drug" and other keywords are searched. A total of 1463 related articles were retrieved. By reading the titles and abstracts of the literature, articles such as non-animal experimental research and application of drug modeling were excluded. 55 articles were initially screened, 33 articles were excluded by reading the full text, and 22 articles were rescreened (Figure 2).

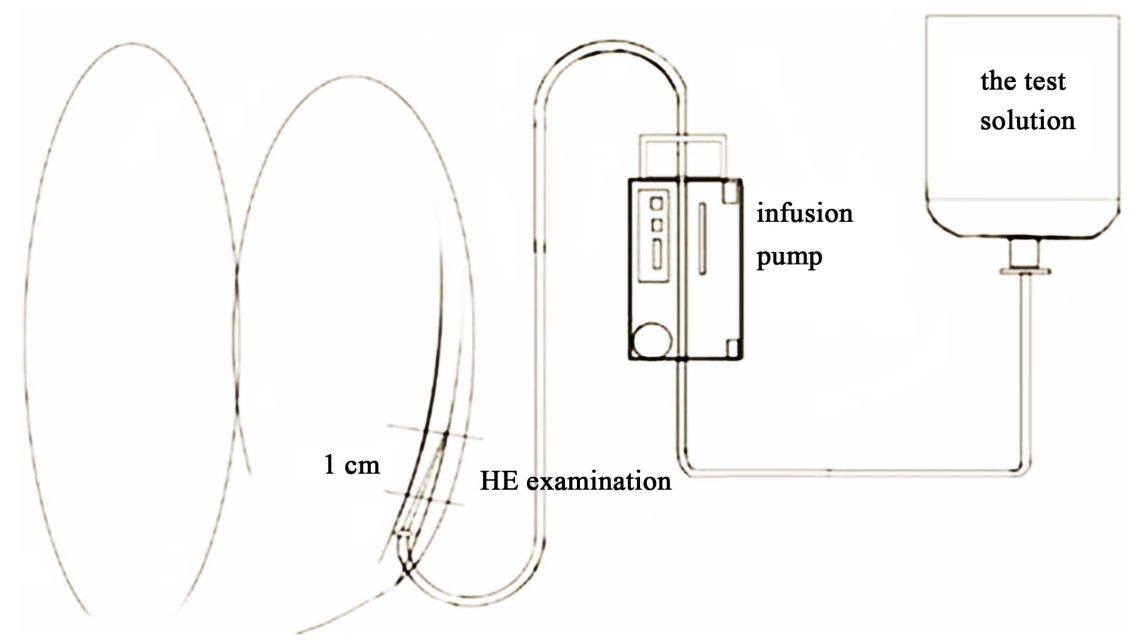

Figure 1. Infusion method for rabbit model of CP (Jing Zhang et al., 2016). 


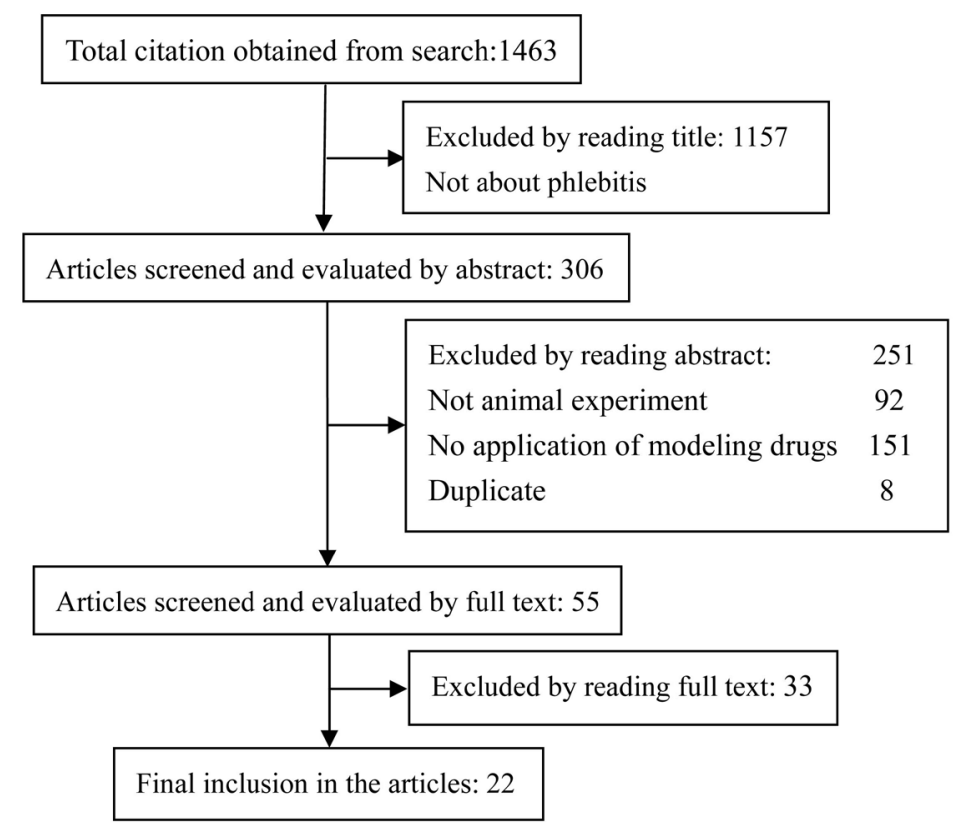

Figure 2. The process and results of screening articles.

\section{Results}

\subsection{Establishment of an Animal Model for CP}

\subsubsection{Establishment of Rabbit Model}

First, $1-2 \mathrm{~d}$ before the experiment, the researchers use depilatory agents ( $8 \%$ sodium sulphides) or razors to remove rabbit hair [4] [6] [7]. A 24G venous indwelling needle is utilized to select the ear vein at a distance of $1-3 \mathrm{~cm}$ from the tip of the ear as the puncture site, marking them with gentian violet/methyl violet solution; meanwhile, using $2 \%-3 \%$ sodium pentobarbital, $10 \%$ chloral hydrate or ketamine before puncture. Perform anesthesia with abdominal, intravenous or intramuscular injection [8] [9]. After anesthesia, obtain the dose according to rabbit body weight, body surface area, or on the number of "one" (Table 1). After modeling, rabbit ear veins were examined by naked eye or light transmission for leakage. It can be considered as a successful modeling if no leakage [10] [11] [12] [13].

\subsubsection{Establishment of Mouse Model}

According to the diameter of the blood vessel, different types of needles are selected (for example, the mouse uses the $7 \#$ scalp needle) to puncture the mouse tail vein [14] [15]. Intraperitoneal injection of mice with diazepam and ketamine prior to puncture [15]. After anesthesia, puncturing the proximal and middle 1/3 of the mouse tail vein, and calculating drug dose by weight and infusion. After modeling, the diameter of the mouse tail was observed by an electronic digital caliper to observe the degree of swelling. The degree of swelling is calculated as swelling $(\%)=($ the diameter of the mouse tail after treatment - the diameter of the mouse tail before treatment)/the diameter of the mouse tail before treatment $\times 100 \%$ [5] [14] [15]. 
Table 1. Comparison of dose methods for establishing a rabbit model.

\begin{tabular}{|c|c|c|c|c|c|c|}
\hline Calculation & Unit & Method & Formula & Advantage & Disadvantage & Mainly References \\
\hline Body weight & $\begin{array}{c}\mathrm{mg} / \mathrm{Kg} \\
\text { or } \mathrm{mL} / \mathrm{Kg}\end{array}$ & $\begin{array}{l}\text { It is known that the dose } \\
\text { of A animal per kg body } \\
\text { weight is found by } \\
\text { looking up the table (W) }\end{array}$ & $\begin{array}{c}\text { Dose of B animals } \\
(\mathrm{mg} / \mathrm{Kg})=\text { dose of } \mathrm{W} \\
\times \mathrm{A} \text { animals }(\mathrm{mg} / \mathrm{Kg})\end{array}$ & $\begin{array}{l}\text { Lookup table } \\
\text { calculation is } \\
\text { convenient and } \\
\text { accurate; the most } \\
\text { commonly used } \\
\text { calculation method }\end{array}$ & $\begin{array}{l}\text { The conversion } \\
\text { process is more } \\
\text { complicated }\end{array}$ & $\begin{array}{l}{[1][5][6][9]} \\
{[11][14][15]} \\
{[16][17][18]}\end{array}$ \\
\hline $\begin{array}{c}\text { Body } \\
\text { surface area }\end{array}$ & $\mathrm{mg} / \mathrm{m}^{2}$ & $\begin{array}{l}\text { According to } \\
\text { Meeh-Rubner's formula, } \\
\mathrm{K} \text { is a constant } 10.1 \text {, } \\
\mathrm{W} \text { is the body mass, in } \mathrm{g}\end{array}$ & $\mathrm{A}=\mathrm{K} \times\left(\mathrm{W}^{2 / 3}\right) / 10000$ & Simple calculation & $\begin{array}{l}\text { The K value reports } \\
\text { are slightly different, } \\
\text { and the estimated } \\
\text { value is rough. }\end{array}$ & {$[10][13]$} \\
\hline Number & one of a pair & - & - & Simple & Inaccurate & [17] [19] \\
\hline
\end{tabular}

\subsection{Modeling Drugs for Animal Models of CP}

In experimental studies, drugs that are highly irritating, high in the concentration, high in the osmotic pressure, and low in the $\mathrm{pH}$, which will be used to establish vascular models (Table 2).

\subsubsection{Vinblastine}

Commonly used vinorelbine (VNR) and vincristine (VCR), which are lipophilic drugs that directly cause damage to vascular endothelial cells. They are highly osmotic and can penetrate into extra vascular tissues, causing local vascular inflammatory reactions and imbalance of osmotic pressure inside and outside the cell membrane. Changes in $\mathrm{pH}$, cause severe phlebitis and thrombosis [1] [12]. Wang et al. [13] according to the dose of human chemotherapy, intravenous low-dose $\left(12.5 \mathrm{mg} / \mathrm{m}^{2}\right)$, medium dose $\left(25 \mathrm{mg} / \mathrm{m}^{2}\right)$ and high dose $\left(50 \mathrm{mg} / \mathrm{m}^{2}\right)$ VNR in rabbit ears, while the control group is injected with $10 \mathrm{~mL}$ of normal saline. The infusion pump is utilized to control the rate, and the infusion is completed in $15 \mathrm{~min}$. The results show that the medium dos and high dose of VNR have typical phlebitis pathology at $48 \mathrm{~h}$.

\subsubsection{Doxorubicin}

Doxorubicin (DXR) is a foaming agent chemotherapeutic drug, which easily damages cell membrane lipids and DNA, causing chemical damage to blood vessels, and manifesting as local redness, pain, and even local chondrocyte necrosis [21] [22]. Wang et al. [22] found that low-speed (60 mL/h), high concentration $(0.20 \%)$, high capacity $(20 \mathrm{~mL})$ of the ear vein intravenous administration are relative to high speed $(90 \mathrm{~mL} / \mathrm{h})$, low concentration $(0.05 \%)$, low volume $(10 \mathrm{~mL})$ administration. Besides, the degree of phlebitis was observed by the naked eye, and the inflammatory infiltration of vascular endothelial cells was more serious under the microscope.

\subsubsection{0\% Mannitol}

As a hypertonic dehydration solution, 20\% mannitol increases plasma and tissue osmotic pressure during infusion, resulting in dehydration of vascular 
Table 2. List of commonly used drugs for animal models of CP from 2008 to 2018.

\begin{tabular}{|c|c|c|c|c|c|c|c|c|c|}
\hline $\begin{array}{l}\text { Reference, } \\
\text { Year }\end{array}$ & Animal & Drug & $\begin{array}{c}\text { Dose } \\
(\mathrm{mg} / \mathrm{Kg})\end{array}$ & $\begin{array}{l}\text { Concentration } \\
(\mathrm{mg} / \mathrm{mL})\end{array}$ & $\begin{array}{c}\text { Speed } \\
(\mathrm{mL} / \mathrm{min})\end{array}$ & $\begin{array}{l}\text { Infusion } \\
\text { time } \\
(\min )\end{array}$ & $\begin{array}{l}\text { Frequency } \\
\text { (Times/d) }\end{array}$ & $\begin{array}{c}\text { Continuous } \\
\text { dosing days } \\
\text { (d) }\end{array}$ & $\begin{array}{c}\text { Instrument } \\
\text { for controlling } \\
\text { speed }\end{array}$ \\
\hline $\begin{array}{c}\mathrm{Fu}(2018) \\
{[9]}\end{array}$ & $\begin{array}{c}\text { Japanese } \\
\text { white rabbit }\end{array}$ & VNR & 0.5 & - & 0.5 & - & 1 & 2 & - \\
\hline $\begin{array}{c}\text { Dan (2015) } \\
\quad[12]\end{array}$ & Rabbit & VNR & - & - & 1.8 & 5 & - & - & - \\
\hline $\begin{array}{c}\text { Wang (2014) } \\
{[13]^{\mathrm{a}}}\end{array}$ & Rabbit & VNR & $12.5 / 25 / 50^{\mathrm{b}}$ & 1 & - & 15 & 1 & 1 & $\begin{array}{l}\text { Infusion } \\
\text { pump }\end{array}$ \\
\hline $\begin{array}{c}\text { Kohno (2008) } \\
{[20]^{\mathrm{a}}}\end{array}$ & $\begin{array}{c}\text { Japanese } \\
\text { white rabbit }\end{array}$ & VNR & 1.5 & $0.6 / 0.3$ & - & - & 1 & 2 & $\begin{array}{l}\text { Peristaltic } \\
\text { pump }\end{array}$ \\
\hline $\begin{array}{c}\mathrm{Ge}(2017) \\
{[1]}\end{array}$ & $\begin{array}{c}\text { Japanese } \\
\text { white rabbit }\end{array}$ & VNR & 3 & - & $5 \mathrm{k}$ & 30 & 1 & 2 & - \\
\hline $\begin{array}{c}\text { Wang (2014) } \\
{[14]}\end{array}$ & $\begin{array}{c}\text { New Zealand } \\
\text { rabbit }\end{array}$ & VNR & 5 & - & 21 & - & - & - & - \\
\hline $\begin{array}{c}\text { Kohno (2009) } \\
{[21]}\end{array}$ & $\begin{array}{c}\text { Japanese } \\
\text { white rabbit }\end{array}$ & VNR & - & 0.6 & $5 \mathrm{k}$ & 30 & - & 2 & - \\
\hline $\begin{array}{c}\text { Wang (2014) } \\
{[14]}\end{array}$ & C57 Mouse & VNR & 37.5 & $10 \mathrm{~h}$ & $0.75^{\mathrm{m}}$ & - & - & - & - \\
\hline $\begin{array}{c}\text { Zou (2017) } \\
{[5]}\end{array}$ & Mouse & VNR & 56.25 & 10 & $0.25^{\mathrm{m}}$ & - & 1 & 1 & - \\
\hline $\begin{array}{c}\text { Shen (2017) } \\
{[15]^{\mathrm{a}}}\end{array}$ & C57 Mouse & VNR & $\begin{array}{c}18.8 / 28.1 / \\
37.5 / 56.3 / 75\end{array}$ & $2.5 / 5 / 10$ & $0.15 / 0.3 / 0.75^{\mathrm{m}}$ & 10 & - & 7 & $\begin{array}{l}\text { Bolus } \\
\text { pump }\end{array}$ \\
\hline $\begin{array}{c}\text { Zhang (2016) } \\
{[6]^{\mathrm{a}}}\end{array}$ & $\begin{array}{c}\text { New Zealand } \\
\text { rabbit }\end{array}$ & VCR & 0.2 & - & 0.5 & $6 / 12 / 18 / 24^{\mathrm{p}}$ & - & - & $\begin{array}{l}\text { Infusion } \\
\text { pump }\end{array}$ \\
\hline $\begin{array}{c}\text { Kohno (2009) } \\
{[21]}\end{array}$ & $\begin{array}{c}\text { Japanese } \\
\text { white rabbit }\end{array}$ & DXR & - & 1.4 & $2 \mathrm{k}$ & 120 & - & 3 & - \\
\hline $\begin{array}{c}\text { Shen (2017) } \\
{[9]}\end{array}$ & $\begin{array}{c}\text { New Zealand } \\
\text { rabbit }\end{array}$ & DXR & $20^{\mathrm{b}}$ & 2 & 1.5 & - & 1 & 3 & - \\
\hline $\begin{array}{c}\text { Wang (2015) } \\
{[22]^{\mathrm{a}}}\end{array}$ & $\begin{array}{c}\text { Japanese } \\
\text { white rabbit }\end{array}$ & DXR & - & $0.05 / 0.1 / 0.2^{\mathrm{g}}$ & $0.5 / 1 / 1.5$ & - & - & - & - \\
\hline $\begin{array}{c}\mathrm{Li}(2018) \\
{[16]}\end{array}$ & $\begin{array}{c}\text { Japanese } \\
\text { white rabbit }\end{array}$ & Mannitol & $4 \mathrm{~d}$ & - & 1 & - & 2 & 7 & - \\
\hline $\begin{array}{c}\text { Zhang (2012) } \\
{[23]}\end{array}$ & $\begin{array}{c}\text { Japanese } \\
\text { white rabbit }\end{array}$ & Mannitol & $2.5^{\mathrm{d}}$ & - & 0.5 & - & 2 & 2 & - \\
\hline $\begin{array}{c}\mathrm{Ge}(2014) \\
{[24]}\end{array}$ & $\begin{array}{c}\text { New Zealand } \\
\text { rabbit }\end{array}$ & Mannitol & $2.5^{\mathrm{d}}$ & - & - & 5 & 1 & 3 & $\begin{array}{l}\text { Microinjection } \\
\text { pump }\end{array}$ \\
\hline $\begin{array}{c}\text { Song (2014) } \\
{[11]}\end{array}$ & $\begin{array}{c}\text { New Zealand } \\
\text { rabbit }\end{array}$ & Mannitol & $2.5^{\mathrm{d}}$ & - & 8 & - & 2 & 5 & - \\
\hline $\begin{array}{c}\text { Tang (2017) } \\
{[25]^{\mathrm{a}}}\end{array}$ & rabbit & Mannitol & $2.5^{\mathrm{d}}$ & - & - & - & 1 & $0.5 / 1 / 2 / 3 / 4$ & - \\
\hline $\begin{array}{c}\text { Zhang (2016) } \\
{[26]}\end{array}$ & $\begin{array}{c}\text { New Zealand } \\
\text { rabbit }\end{array}$ & Mannitol & $2.5^{\mathrm{d}}$ & - & - & - & 1 & 5 & - \\
\hline
\end{tabular}




\section{Continued}

\begin{tabular}{|c|c|c|c|c|c|c|c|c|c|}
\hline $\begin{array}{c}\text { Chen (2014) } \\
{[17]}\end{array}$ & $\begin{array}{c}\text { New Zealand } \\
\text { rabbit }\end{array}$ & Mannitol & $10^{c}$ & - & - & 15 & 1 & 5 & - \\
\hline $\begin{array}{c}\text { Zhang (2013) } \\
\text { [4] }\end{array}$ & $\begin{array}{c}\text { New Zealand } \\
\text { rabbit }\end{array}$ & Mannitol & $2.5^{\mathrm{d}}$ & - & 0.5 & - & 2 & 2 & $\begin{array}{l}\text { Microinfusion } \\
\text { pump }\end{array}$ \\
\hline $\begin{array}{c}\text { Mo (2015) } \\
{[19]}\end{array}$ & $\begin{array}{c}\text { New Zealand } \\
\text { rabbit }\end{array}$ & Mannitol & $10^{c}$ & - & - & 15 & - & - & - \\
\hline $\begin{array}{l}\text { Kuwahara } \\
(2009)[27]^{\mathrm{a}}\end{array}$ & $\begin{array}{c}\text { Japanese } \\
\text { white rabbit }\end{array}$ & $\mathrm{AF}$ & - & - & $5^{\mathrm{kn}} / 15^{\mathrm{ko}}$ & - & 1 & $1^{\mathrm{q} / 3^{\mathrm{r}}}$ & $\begin{array}{l}\text { Infusion } \\
\text { pump }\end{array}$ \\
\hline $\begin{array}{c}\text { Yang (2017) } \\
{[18]^{\mathrm{a}}}\end{array}$ & Rabbit & Amiodarone & $8^{\mathrm{e}} / 20^{\mathrm{f}}$ & $1.5^{\mathrm{i} / 1.8^{\mathrm{j}}}$ & - & $1 / 2 / 3 / 4 / 5^{\mathrm{p}}$ & - & - & - \\
\hline
\end{tabular}

"a" in the reference represents the treatment of different methods; In the dose, "b" unit is $\mathrm{mg} / \mathrm{m}^{2}$, "c" unit is $\mathrm{mL} / \mathrm{single}$, "d" unit is $\mathrm{mL} / \mathrm{Kg}$, "e" is $8 \mathrm{~min}$ before infusion, " $\mathrm{f}$ " is $6 \mathrm{~h}$ after infusion; In the speed, " $\mathrm{k}$ " unit is $\mathrm{mL} / \mathrm{Kg} / \mathrm{h}$, "l" unit is $\mathrm{mg} / \mathrm{min}$, " $\mathrm{m}$ " unit is $\mu \mathrm{L} / \mathrm{s}$, " $\mathrm{n}$ " means continuous infusion, " $\mathrm{o}$ " means intermittent infusion; In the infusion time, "p" unit is hour; In the continuous dosing days, "q" means continuous infusion, " $r$ " means intermittent infusion; "VNR" means Rvinorelbine, "VCR" means Vincristine, "DXR" means Doxorubicin, "Mannitol" means 20\% Mannitol, "AF" means 3\% amino acid/7.5\% glucose solution; "-" in the full table means no.

endothelial cells and local platelet aggregation, thereby inducing vascular endothelial injury and apoptosis. At the same time, the release of prostaglandins activates inflammation, Mediation and leukocyte invasion, and release of histamine causes vasoconstriction and hardening [11] [16] [17] [19]. Experimental studies often use $2.5 \mathrm{~mL} / \mathrm{Kg}$ doses or $10 \mathrm{~mL}$ infuse into the ear vein, and the model of CP was established by continuous drug for 2 - 7 days (Table 1). Tang et al. [25] showed that the main component of fibrin sheath contains red blood cells, thrombus, collagen fibers, cellulose and some cellular components, which is found by HE and Masson staining, by using the method of the infusion of $20 \%$ mannitol in rabbit ears.

\subsubsection{Parenteral Nutrition Solution}

Parenteral nutrition solution (PPN) is a hypertonic (600 - $900 \mathrm{mOsm} / \mathrm{kg})$, acidic solution, causes chemical stimulation of peripheral veins, venous injury and $\mathrm{CP}$ [27]. Kuwahara et al. [27] used 3\% amino acid/7.5\% glucose solution (AF), osmotic pressure $856 \mathrm{mOsm} / \mathrm{kg}, \mathrm{pH}$ 6.6, modeling rabbit ear vein. The results showed that there was a significant venous endothelial cell loss and peril vascular tissue edema in the continuous infusion group $(5 \mathrm{~mL} / \mathrm{kg} / \mathrm{h}, 24 \mathrm{~h}$ ), while the intermittent infusion group $(15 \mathrm{~mL} / \mathrm{kg} / \mathrm{h}, 8 \mathrm{~h} \times 3 \mathrm{~d})$ had no significant changes in the veins.

\subsubsection{Amiodarone}

The $\mathrm{pH}$ value changes from 2.5 to 4.0 , which is highly irritated to blood vessels and easily damages blood vessels, causing CP [18]. Yang et al. [18] showed that a moderate inflammatory reaction is observed under the microscope, when the rabbit ear vein infusion lasts for $3 \mathrm{~h}$, through using the amiodarone model. Besides, as the infusion time prolongs, the inflammatory infiltration range will expand, and a large number of necrotic cells and severe vascular endothelium could be observed in the lumen after $5 \mathrm{~h}$. 


\subsection{The Key Factors Affecting the Successful Establishment of CP}

Dosing amount, concentration, speed and time are the key factors affecting the successful modeling of CP. Through the reading of the literature, there are 8 articles using different methods to compare the effects of establishing a CP model. The methods have their own advantages and disadvantages in the application of modeling (Table 3).

\subsubsection{Medication Dose}

When a large amount of drug flows into the vein, which continues to stimulate the inner wall of the blood vessel, causing harm to the wall. As the dose increases, the time for the drug remaining in the blood vessel is prolonged, and the risk of CP increases as well [15] [22]. Wang et al. [13] indicated that the incidence of phlebitis in each group was $42.9 \%, 85.7 \%$ and $100 \%$ respectively after injecting low, medium and high doses of VNR into rabbit model.

\subsubsection{Medication Concentration}

The high concentration on the drug entering the vascular drug, the large amount of the drug in contact with the vascular endothelium, and the high degree of damage to the blood vessel and surrounding tissues, which will be more likely to cause the tissue damage [15] [20] [22]. Kohno et al. [20] found that venous endothelial cell shedding, inflammatory cell infiltration, high edema in the group of high-concentration and low-speed (concentration $0.6 \mathrm{mg} / \mathrm{mL}$, speed 5 $\mathrm{mL} / \mathrm{Kg} / \mathrm{h}$ ) infused with $\mathrm{VNR}$ in the rabbit ear vein, slightly higher than the low-concentration high-speed group (a concentration $0.3 \mathrm{mg} / \mathrm{mL}$, speed of 10 $\mathrm{mL} / \mathrm{Kg} / \mathrm{h})$. However, the effect of the two groups was not statistically significant $(P>0.05)$. The difference of epidermal degeneration between these two groups had statistically significant $(\mathrm{P}<0.05)$ due to the drug input of vein, but some of drug contacts to the inner wall of the blood vessel, thereby stimulating the damage to the vascular endothelium and increasing the permeability of the blood

Table 3. Advantages and disadvantages of different methods in the application of CP modeling drugs.

\begin{tabular}{|c|c|c|c|}
\hline Method & Advantage & Disadvantage & Mainly References \\
\hline Dose & $\begin{array}{l}\text { There are conversion formulas such as weight } \\
\text { or body surface area; More accurate calculation }\end{array}$ & $\begin{array}{l}\text { The effective amount used in different animals } \\
\text { is inconsistent; Excessive dose can cause } \\
\text { death of small animals }\end{array}$ & {$[13][15]$} \\
\hline Speed & $\begin{array}{l}\text { Fast onset, high bioavailability, easy to control } \\
\text { blood concentration }\end{array}$ & $\begin{array}{l}\text { The speed is difficult to control, resulting in } \\
\text { inaccurate results; Need infusion pump, syringe } \\
\text { pump and other instruments to control the speed }\end{array}$ & {$[15][21][22][27]$} \\
\hline Concentration & $\begin{array}{l}\text { Simple and convenient to use the } \\
\text { dilution method }\end{array}$ & $\begin{array}{l}\text { There is no standard conversion formula to rely on; } \\
\text { Inaccurate estimates can lead to animal } \\
\text { poisoning reactions }\end{array}$ & {$[15][21][22]$} \\
\hline Time & $\begin{array}{l}\text { Effectiveness, increase the success rate } \\
\text { of modeling; } \\
\text { Correlation, associated with dose, } \\
\text { speed, and concentration }\end{array}$ & $\begin{array}{l}\text { There is a lack of standard standards for medication } \\
\text { time, time interval and days of modeling }\end{array}$ & {$[18][25][27]$} \\
\hline
\end{tabular}


vessel. Meanwhile, drug in the lumen penetrates into the surrounding tissue of the blood vessel, and reaches the epidermis, causing epidermal degeneration. In addition, the drug concentration of the mouse model was divided into high-concentration group $(10 \mathrm{mg} / \mathrm{mL})$, medium-concentration group $(5 \mathrm{mg} / \mathrm{mL})$ and low-concentration group $(2.5 \mathrm{mg} / \mathrm{mL})$ under the same dose and speed.

\subsubsection{Medication Speed}

When the drug enters the blood in a low speed, it gradually forms a laminar flow with the blood and mixes with each other. If the blood cannot fully neutralize the drug, the drug contacts stimulate the vascular endothelial cells, causing damage [20] [22]. Kohno et al. [20] concluded that at the same concentration, low speed group $(5 \mathrm{~mL} / \mathrm{Kg} / \mathrm{h})$ is more easily to cause vascular endothelial cell shedding, inflammatory cell infiltration, epidermal degeneration than high speed group $(15 \mathrm{~mL} / \mathrm{Kg} / \mathrm{h})$. However, some scholars believe that when the drug speed is greater than the blood flow rate, the blood cannot dilute the drug concentration in time, thereby aggravating the chemical stimulation of the blood vessel to the vascular endothelium, increasing the permeability of the blood vessel, and causing the drug to ooze out to the surrounding tissue of the blood vessel. Besides, the damage to surrounding tissues [15] [22].

\subsubsection{Medication Time}

When the stimulant drug is put into the vein, which will stimulate the blood vessel to damage the vascular endothelium; and if the infusion continues, the drug accumulates in the damaged area, surpassing the stress ability of the blood vessel. As a result, it will damage the intima of the blood vessel, and aggravate the occurrence of phlebitis as well [20] [22] [27]. Zhang et al. [3] studied the severity of phlebitis by searching the length of VCR infusion time. This study found that phlebitis was respected by the naked eye after $12 \mathrm{~h}$, and the loss of venous endothelial cells was observed by histopathology after $6 \mathrm{~h}$. As a result, longer infusion time, the more severe phlebitis. Tang et al. [25] took samples of HE and Masson at different time (12 h, 1, 2, 3, 4 d) after 20\% mannitol modeling, and found that fibrin begin to form in the vascular cavity after $12 \mathrm{~h}$ administration. With the prolonged administration time, the percentage of cross-sectional area accounting for the lumen area $(\%)$ also increased significantly $(\mathrm{P}<0.001)$.

\section{Discussion}

A number of studies have established animal models of $\mathrm{CP}$ and then given different interventions to prevent and treat phlebitis. The success of CP directly affects the subsequent experimental results.

There are also many models for CP research. Currently, the types of animals are mainly rabbits and mice. Other animals have rarely been reported. Common rabbit species include Japanese white rabbits, New Zealand rabbits, and rabbits, weighing about 2.0 - 3.0 $\mathrm{Kg}$ (Table 2). Some researchers select male rabbits [20] [27], while the other part is not limited to males and females [18] [22] [25]. Be- 
cause female rabbits not only have light weight, blood vessels are fine, but also secreted estrogen affects blood vessels. It is recommended that rabbits in the CP model be easy to select males in the future. The mouse model is also a small animal that is often selected. The use of standard inbred C57 mice increased the reliability of the experimental data relative to normal mice [14] [15]. However, the tail vein of the mouse is difficult to puncture. If the dose and concentration are too high, the mortality of the mice is increased. Shen et al. [15] injected VNR at the same concentration and speed into the tail vein of mice, and the dose varied from low to high of $18.8,28.1,37.5,56.3$ and $75 \mathrm{mg} / \mathrm{Kg}$, respectively. The results showed that the higher dose of the drug, the higher incidence of sinusitis ( $\mathrm{P}=$ 0.006 ), and the mortality of the high-dose group ( 56.3 and $75 \mathrm{mg} / \mathrm{Kg}$ ) was $25.0 \%$. $50.0 \%$. In addition, they also found that the incidence of phlebitis in the three groups was $100 \%$, no mice died in the high-concentration group, and the mortality rates in the middle and low-concentration groups were $50.0 \%$ and $62.5 \%$ respectively. The reason for explain that the size of mouse is smaller than the rabbit model, so the circulating blood volume is small. The one-time infusion amount cannot be effectively metabolized in the body, because too much accumulation is likely to result in poisoning death. Therefore, it is important for us to focus on maintaining the gradient and total amount of the while modeling the mice, which can help prevent the high mortality rate of the mice from affecting analysis results.

The drugs commonly used in modeling drugs are chemotherapeutic drugs such as VNR, DXR, etc., hypertonic drugs such as mannitol. The common feature of these drugs is that they are more irritating and easily damage blood vessels, making it easier to establish a CP model. Shen et al. [15] found that when the mice were injected with VNR at a dose of $37.5 \mathrm{mg} / \mathrm{Kg}$ and a concentration of $10 \mathrm{mg} / \mathrm{mL}$, the incidence of phlebitis was $100 \%$ and no mice died; when the speed was $0.3 \mu \mathrm{l} / \mathrm{s}$, the incidence of phlebitis was higher than in other speed groups ( $75 \%$ vs $33.3 \%, 25 \%$ ), and no mice died. Therefore, it can conclude that the appropriate dose of VNR in mice is $37.5 \mathrm{mg} / \mathrm{Kg}$, or $25 \mathrm{mg} / \mathrm{m}^{2}$, the concentration is $10 \mathrm{mg} / \mathrm{mL}$, and the speed is $0.3 \mu \mathrm{l} / \mathrm{s}$ [13] [15]. In addition, Shen et al. [10] simulated clinical chemotherapy courses, used a dose of $20 \mathrm{mg} / \mathrm{m}^{2}$, a rate of 90 $\mathrm{mL} / \mathrm{h}$ intravenous infusion of DXR which administered at the first, third, and fifth weeks to establish a model. This modeling mode is in line with the actual clinical use of drugs, and can provide a more accurate reference for the prevention of patients with CP. Mannitol is a commonly used dehydrating agent for brain damage. Because of high permeability, it is often used as a model drug for $\mathrm{CP}$. However, some researchers injected $10 \mathrm{~mL}$ intravenously into the ear of each rabbit [17] [19] (Table 2). The weight of each rabbit is different, but the medication is the same, which will lead to inconsistent modeling effects and affect the experimental results. Therefore, the dose of the animal is recommended to use the body weight or surface area to convert the calculation, rather than counting the number of medications. 
There are references using a single factor to compare the effects of different levels of parameters on the establishment of CP [13] [18] [25] (Table 3). A number of factors were combined to compare the effects of the model establishment, such as the combination of dose, concentration and speed, the combination of speed and number of days of administration [15] [22] (Table 3). There are even simulated clinical rinsing and before and after infusion to observe the impact on the CP model [20].

At present, the researchers agree that factors such as dose, concentration and time of administration are positively correlated with vascular endothelial injury. Therefore, the higher the dose, the higher the incidence of CP. But, researchers at home and abroad hold opposing views on the effects of drug rates on $\mathrm{CP}$. One view is that low-speed medication is easy to cause $\mathrm{CP}$, the other is that high-speed medication is easy to cause CP. Kuwahara et al. [27] injected AF into the rabbit ear vein at low-speed $(5 \mathrm{~mL} / \mathrm{Kg} / \mathrm{h})$ and high-speed $(15 \mathrm{~mL} / \mathrm{Kg} / \mathrm{h})$, and found that the low speed group is more prone to phlebitis than the high speed group $(\mathrm{P}<$ 0.05). Shen et al. [19] found that the incidence of CP in the high speed group $(0.75 \mu \mathrm{l} / \mathrm{s})$, medium-speed group $(0.3 \mu \mathrm{l} / \mathrm{s})$ and low speed group $(0.15 \mu \mathrm{l} / \mathrm{s})$ of VNR in the tail vein of mice is $33.3 \%, 75.0 \%$ and $25 \%$ respectively. The incidence of phlebitis in the moderate speed group was higher than the low speed group ( $\mathrm{P}$ $<0.05)$. What's more, there is no mouse died in the middle and low speed groups, while 5 mice died in the high speed group. The reason explained for the results may be the differences in animal models, the different anatomical locations of the mouse tail and the rabbit ear vein, the thickness of the wall and the ability to tolerate stimulating drugs, which may require further research in the future.

\section{Conclusion}

Not only will accurate use of animal models pave the way for further prevention and treatment of $\mathrm{CP}$, but also provide a reference for the clinical rational use of drugs. It can be viewed on this review that rabbits are mainly modeled animals, followed by rodents, and other large animals are rarely reported in the experimental studies. The size of rabbits and mice is very small compared to humans, so their circulatory and vascular conditions are quite different from those of clinical patients. In the future, studied animals should be closer to human body types, and also can add animal models simulating clinical patients, such as various types of cancer, diabetes, and cerebral edema. In the current research, the drug dose is calculated by the body weight or body surface area of the animal, and only a few researchers use the amount of modeling drugs as the units according to the number of animals. Although this method is simple, it will have a negative effect on the research result. Therefore, it is not recommended to use drugs based on the number of animals. Besides, in terms of the speed effects on $\mathrm{CP}$, altered animal models present different results and conclusions, which need further research and discussion. Recently, despite the fact that there are many 
types of drugs for modeling phlebitis, the drugs used in the specific experiments are relatively simple, and they are not fully compatible with the actual clinical combination. In the future research, modeling drugs can be diversified and more in line with clinical practice.

\section{Acknowledgements}

This study is supported by the Hubei Medical and Health Science and Technology Plan Project (2017-97). And the third batch of joint fund project of Hubei Provincial Health and Family Planning Commission (WJ2018H231).

\section{Conflicts of Interest}

The authors declare no conflicts of interest regarding the publication of this paper.

\section{References}

[1] Ge, G.F., Shi, W.W., Yu, C.H., Jin, X.Y., Zhang, H.H., Zhang W.Y., et al. (2017) Baicalein Attenuates Vinorelbine-Induced Vascular Endothelial Cell Injury and Chemotherapeutic Phlebitis in Rabbits. Toxicology and Applied Pharmacology, 318, 23-32. https://doi.org/10.1016/j.taap.2017.01.013

[2] Chi, Y., Wang, D. and Li, H.Y. (2016) Herapeutic Effect of Wet Compress of Magnesium Sulfate Combined with Vitamin B12 on Chemotherapy-Induced Phlebitis in Rabbits. International Journal of Clinical and Experimental Medicine, 9, 12356-12360.

[3] You, Y.H. and Liu, R.T. (2018) Application of Ji Desheng Snake Pills Combined with Hypertonic Glucose External Application in Treating Drug-Induced Superficial Phlebitis Caused by Parenteral Nutrition. Yangtze Medicine, 2, 108-113. https://doi.org/10.4236/ym.2018.22012

[4] Zhang, J.H., Wang, H.F., Gui, Y.L., Li, W. and Zhou, W. (2013) Influence of Compound Aescine Gel on Nltrastructure of Vein Infused Mannitol and Its Mechanism. Acta Cirurgica Brasileira, 1, 30-35.

[5] Qiu, M., Liu, L., Zou, W.J. and Sun, K. (2017) Effect of Hu Mai Powder on the Expression of E-Selectin and ICAM-1 in Vascular Endothelial Cells of Mice with Phlebitis. Journal of Basic Chinese Medicine, 23, 1224-1228. (In Chinese)

[6] Zhang, J., Shen, J., Yin, W.W., Wei, X.Y., Wu, L.G. and Liu, H. (2016) The Intervention Research on Treatment by Xianchen to Rabbits Model of Chemotherapeutic Phlebitis. Acta Cirurgica Brasileira, 31, 549-556.

https://doi.org/10.1590/S0102-865020160080000008

[7] Wang, A.S., Luo, P.F., Qin, C.C., Zhang, L., Li, X., Yang, P., et al. (2015) Changes of Inflammatory Cytokines in Indwelling Needle-Induced Local Arterial Injury. Journal of Nursing, 22, 1-4. (In Chinese)

[8] Zhang, X.P., Su, Y., Zhang, Q.Q. and Wang, X.M. (2015) Effect of Fufang Sanqi Powder on the Prevention of Phlebitis Caused by Venous Indwelling. Nursing Journal of Chinese People's Liberation Army, 32, 13-16. (In Chinese)

[9] Fu, X.Y., Su, Y., Yan, C.L., Liu, Y.Q. and Zhang, G.Z. (2018) The Mechaanism of Potato Glycoalkaloids in Relieving Phlebitis Induced by Intravenous Infusion of Antineoplastic Agents in Rabbit. Journal of Nursing Science, 33, 31-33. (In Chinese) 
[10] Shen, J., Fan, Y.M., Zhao, X.Y., Cheng, Y.X., Wei, X.H., Sun, W.J., et al. (2017) Effects of Two Intravenous Administration Routes of Doxorubicin on Myocardial Enzymes in Rabbit. Journal of Nursing Science, 32, 42-45.

[11] Song, L.X., Zhang, Y.M., Wang, L., Xu, H.P., Huang, Q. and Lu, M.L. (2014) Study on the Test of Giant Knotweed Cream Prevention of Mannitol-Induced Rabbit Rar Superficial Venous Injury. Nursing Practice and Research, 11, 6-7.

[12] Shan, Z.Z., Zhou, L.Y., You, J.L., Zhang, C.C. and Gong, S.X. (2015) Effects and Safety of External Application of Fumai Paste on Chemotherapeutic Ears Phlebitis in Rabbits. Hebei Journal of Traditional Chinese Medicine, 37, 1515-1518. (In Chinese)

[13] Wang, H., Wu, T.T., Lu, H.F., Song, M. and Yang, B. (2014) An Animal Model of Vinorelbine Induced Phlebitis. Journal of Nursing Science, 29, 19-21. (In Chinese)

[14] Wang, Z., Ma, L., Wang, X., Cai, H.P., Huang, J., Liu, J.Y., et al. (2014) Cimetidine Attenuates Vinorelbine-Induced Phlebitis in Mice by Militating E-Selectin Expression. Cancer Chemotherapy and Pharmacology, 74, 239-247. https://doi.org/10.1007/s00280-014-2487-8

[15] Shen, J.B., Yu, Z.R., Li, Y.H., Cao, M. and Cui, Y.L. (2017) The Role of Vinorelbine in the Establishment of a Mouse Model of Infusion Phlebitis and Its Intervention. Chinese Journal of Gerontology, 37, 4980-4981. (In Chinese)

[16] Li, G., Litscher, G., Pang, H., Yang, B.Z., Litscher, D. and Wang, L. (2018) Experimental Study of Phlebitis Ointment Administration in Acute Superficial Thrombophlebitis. Evidence-Based Complementary and Alternative Medicine, 2018, Article ID: 2983195.

[17] Chen, G.Y., Jing, L.P., Huang, L.Q., Liu, Q.W. and Shi, H.Q. (2014) Establishment of Animal Model of Phlebitis and the Expression of TNF- $\alpha$, ICAM-1. Journal of Nursing Science, 29, 6-9. (In Chinese)

[18] Yang, J., Guo, J.L. and Qi, L.X. (2017) Discussion on the Time of Continuous Intravenous Infusion of Amiodarone Hydrochloride Injection for Intravenous Indwelling Needle. Journal of Clinic Nursing's Practicality, 2, 178-179. (In Chinese)

[19] Mo, X.R., Luo, X.J., Li, C.P., Pan, X.F. and Zhou, L.L. (2015) Effect of Mannitol Injection by Intravenous Catheter on Ear Vein Endothelial Cell Apoptosis and Venous Thrombus in Rabbits. European Review for Medical \& Pharmacological Sciences, 19, 491-497.

[20] Kohno, E., Murase, S., Nishikata, M., Okamura, N., Matzno, S., Kuwahara, T., et al. (2008) Methods of Preventing Vinorelbine-Induced Phlebitis: An Experimental Study in Rabbits. International Journal of Medical Sciences, 5, 218-223. https://doi.org/10.7150/ijms.5.218

[21] Kohno, E., Murase, S., Matsuyama, K. and Okamura, N. (2009) Effect of Corticosteroids on Phlebitis Induced by Intravenous Infusion of Antineoplastic Agents in Rabbits. International Journal of Medical Sciences, 6, 218-223. https://doi.org/10.7150/ijms.6.218

[22] Wang, D., Li, H.Y., Lu, P.P., Xiao, Y. and Hui, C.Y. (2015) Experimental Study on Doxorubicin Hydrachloride Induced Venous Injury by Using Different Drug Delivery Methods. Journal of Nursing Science, 30, 56-58. (In Chinese)

[23] Zhang, Z., Zhang, Q., Wang, P., Pan, X., Zhao, Q.X. and Wang, X.K. (2012) Effects of Anisodamine on the Expressions of Tumor Necrosis Factor- $\alpha$ and Cycloxygenase 2 in Experimental Infusion Phlebitis. Life Science Journal, 9, 533-539.

[24] Ge, G.H., Fang, J., Hu, Y.X. and Yu, C.H. (2014) Effect of Rhubarb Extract on CNF- $\kappa$ B Expression in Phlebitis of Rabbit Ear. Zhejiang Journal of Traditional Chi- 
nese Medicine, 49, 303-304. (In Chinese)

[25] Tang, W.S., Liao, H.T., Qin, H.M., Qin, Y. and Wei, Y.P. (2017) Development a Rabbit Model of Venous Indwelling Catheter Related Fibrin Sheath. Journal of Youjiang Medical University for Nationalities, 39, 260-263. (In Chinese)

[26] Zhang, L.F., Lu, M.M., Liao, H.T., Wei, Y.P., Li, L.C. and Deng, T. (2016) The Effect of Low-Molecular-Weight Heparin on Serum D-Dimer and Vonwillebrand Factor in the Rabbit Model of Intravenous Catheter Induced Thrombosis. Journal of Guangxi Medical University, 33, 942-946. (In Chinese)

[27] Kuwahara, T., Kaneda, S., Sawamoto, O. and Kohno, E. (2009) Cyclic Infusion Is Effective in Reducing Phlebitis Caused by Peripheral Parenteral Nutrition Solutions: An Experimental Study in Rabbits. e-SPEN, the European e-Journal of Clinical Nutrition and Metabolism, 4, e344-e347. https://doi.org/10.1016/j.eclnm.2009.10.003 